\title{
Correlation and Path Analysis in China Aster [Callistephus chinensis (L) Nees]
}

\author{
D. Naikwad*, K. Kandpal, M.G. Patil, A. Hugar and V. Kulkarni \\ Department of Horticulture, University of Agricultural Sciences, Raichur, Karnataka, \\ Raichur-584102, Karnataka, India \\ *Corresponding author
}

\section{Keywords}

China aster,

Correlation, Path analysis

Article Info

Accepted:

28 January 2018

Available Online:

10 February 2018

\section{A B S T R A C T}

The study was conducted on correlation and path analysis among the different characters influencing the flower yield of twelve different genotypes of China aster. The experiment was carried out in Randomized Block Design during kharif season of 2016-17 under semi-arid climatic condition at Experimental block of Department of Horticulture, College of Agriculture, UAS, Raichur. Correlation among the different characters influencing the number of leaves, number of secondary branches plant ${ }^{-1}$ and plant spread showed significant positive correlation with yield both at phenotypic and genotypic level suggesting good scope for improvement of yield. The results for path analysis indicated that test weight (10 flower weight), number of secondary branches plant ${ }^{1}$ and number of flowers plant ${ }^{1}$ directly influenced the flower yield and had maximum direct effect. This result suggests that these traits can be directly used to improve the yield of China aster.

\section{Introduction}

The evolution of China aster [Callistephus chinensis (L.) Nees] has a history of remarkable variations.

According to Emsweller et al., (1937), the original plant had single flowers with two or four rows of blue, violet or white ray florets. The stature was medium tall and height of the plant ranged from 18 to 24 inches. The first change in the flower type had been the prolongation or development of central florets and the production of quilled flowers. Germans developed double forms in aster during $18^{\text {th }}$ century. Hence, asters are also called as German asters. Advancement of the aster evolution and large scale seed production by Germans led to the introduction of branching types, tall types, medium tall and dwarf types and this contributed for great evolutionary improvement in China aster. 
China aster [Callistephus chinensis (L.) Nees] belongs to one of the largest families of flowering plants, 'Asteraceae'. The present day asters have been developed from a single form of wild species known as, Callistephus chinensis. The name of the genus 'Callistephus' is derived from two Greek words 'kalistos' meaning 'most beautiful' and 'stephos', a crown, referring to the flower head. The genus Callistephus has only a single species, namely, Callistephus chinensis. It is native to China and has spread to European countries and other tropical countries during 1731 AD (Desai, 1967). China aster is one of the most important annual flower crops grown in most parts of the world.

China aster is a free blooming half hardy, easy growing winter annual crop grown for cut flower as well as loose flower. The bloom type depends mainly upon the relative number of the two kinds of florets and their shapes. The most suitable character for the classification of China aster is the shape of ray florets. The present day varieties are available in diverse forms, different types and a wide spectrum of colour ranges viz., pink, primrose, pale blue, mauve, purple, scarlet, creamy white, pure white, violet etc.

\section{Materials and Methods}

The experiment was carried out in Randomized Block Design with three replications in the Experimental block of Department of Horticulture, College of Agriculture, UAS, Raichur during the year of 2016-17. Twelve different varieties viz., Kamini, Shashank, Poornima, Arka Aadya, Arka Archana, Phule Ganesh white, Phule Ganesh Pink, Phule Ganesh Purple, Phule Ganesh Violet, Mudigere Local, Namdhari Pink and Namdhari White were used for the study. Spacing of $50 \mathrm{~cm}$ between replications and $30 \mathrm{~cm}$ between two plots were provided for laying out the bunds. The entire experimental land was divided into subplots measuring $3.6 \mathrm{~m} \mathrm{x} 3.0 \mathrm{~m}$ and there were totally 36 plots. Forty days old healthy and uniformly grown seedlings were transplanted with a spacing of $30 \times 30 \mathrm{~cm}$. The optimum irrigation was given soon after transplanting. Five randomly selected plants from each genotypes and replication were tagged for recording the observations after discarding the border plants at both the ends.

The observations were recorded on quantitative characters selected for correlation studies are plant height, plant spread $(\mathrm{cm})$, Number of leaves, Number of primary branches, Number of secondary branches, Leaf area $\left(\mathrm{cm}^{2}\right)$, Leaf area index, Dry matter (g), Days to flower bud initiation, Days to flowering, Days for $50 \%$ flowering, Duration of flowering (days), Number of flowers/plant, Flower diameter $(\mathrm{cm})$, Test weight $(\mathrm{g})$ and yield/plant. The observed data were subjected to statistical analysis. Fisher's method of analysis of variance was applied for the analysis and interpretation of data as given by Panse and Sukhatme (1967). The path coefficient analysis was carried out by using the technique outlined by Dewey and $\mathrm{Lu}$ (1959) for flower yield and its components keeping flower yield as resultant variable and its component as causal variables.

\section{Results and Discussion}

Knowledge of degree of association of yield with its components is of great importance, because yield is not an independent character, but it is the resultant of the interactions of a number of component characters among themselves as well as with the environment in which the plant grows. Further each character is likely to be modified by action of genes present in the genotypes of plant and also by the environment and it becomes difficult to evaluate this complex character directly. Therefore, correlation study of yield with its 
component traits has been executed to find out the yield contributing traits.

\section{Phenotypic correlation coefficient}

The phenotypic correlation coefficient among different characters showed that flower yield per plant had the positive and highly significant association with number of leaves (0.7850), number of secondary branches (0.7844), plant spread (0.7649), leaf area index (0.7542), flower size (0.7306), leaf area (0.6930), plant height (0.6820), dry matter (0.6691), test weight $(0.5774)$ and number of primary branches $(0.5151)$.

Besides, plant spread (0.7649) had positive and significant association with number of secondary branches (0.7873), number of leaves $(0.7850)$ had positive and significant association with leaf area index (0.8216), number of primary branches $(0.5151)$ with leaf area index (0.6525), number of secondary braches (0.7844) had significantly positive association with leaf area index (0.8704), dry matter (0.8572), leaf area (0.8087), flower size (0.8063) and test weight (0.6505). Significantly positive association of leaf area (0.6930) with leaf area index (0.9275). Leaf area index (0.7542) had positive and significant association with dry matter (0.8678), flower size (0.8240). Dry matter (0.6691) recorded positive and significant association with flower size (0.7841) and test weight (0.5509).

Days to flower bud initiation had significantly positive association with days to first flowering (0.9768), days to 50 per cent flowering (0.9388). Significantly positive association of days to first flowering with days to 50 per cent flowering (0.9500), test weight $(0.5566)$ and flower size (0.5380). Days to 50 per cent flowering had positive and significant association with test weight (0.6217) and number of primary branches (0.5382). Flower size (0.7306) recorded positive and significant association with test weight (0.5698) the result is in substantiation with Baweja (2000), Zosiamliana et al., (2012) and Shantappa et al., (2015) (Fig. 2 and Table 1).

\section{Genotypic correlation coefficient}

Genotypic correlation coefficient among different characters showed that flower yield per plant had positive and significant association with number of leaves per plant (0.8970), plant spread (0.8135), number of secondary branches $(0.8123)$, plant dry matter (0.8058), leaf area index (0.7959), flower size (0.7861), plant height $(0.7159)$, leaf area (0.7104), number of primary branches per plant (0.6659) and test weight (0.5947) (Fig. 1 and 3; Table 2 and 3).

Besides, days to flowering recorded positive and significant association with days to 50 per cent flowering (0.9855), test weight $(0.5747)$ and flower size (0.4894). Significant and positive correlation of days to flower bud initiation with days to 50 per cent flowering (0.9734). Plant height (0.7159) recorded significantly positive correlation with leaf area index (0.9689) leaf area (0.9678). Significantly positive correlation of leaf area (0.7104) with leaf area index (0.9659). Number of primary branches (0.6659) showed significantly positive correlation with dry matter (0.9639). Significant and positive correlation of number of secondary branches (0.8123) with dry matter (0.9601). Leaf area index (0.7959) recorded significantly positive correlation with dry matter (0.9554). Significant and positive correlation of number of leaves (0.8970) with leaf area index (0.9217). Dry matter (0.8058) had significantly positive correlation with flower size (0.8931) and test weight (0.7861). Significant and positive correlation of plant spread (0.8135) with dry matter (0.8627). Number of flowers per plant had significantly positive correlation with test weight (0.6462). 
Table.1 Phenotypic co-efficient of correlation among traits in China aster

\begin{tabular}{|c|c|c|c|c|c|c|c|c|c|c|c|c|c|c|c|}
\hline & $\mathrm{X} 2$ & $\mathrm{X3}$ & $\mathrm{X} 4$ & X5 & X6 & $\mathrm{X} 7$ & X8 & X9 & $\mathrm{X} 10$ & X11 & $\mathrm{X} 12$ & X13 & X14 & X15 & X16 \\
\hline $\mathrm{X} 1$ & $0.6489 * *$ & $0.7915^{* *}$ & $0.6332 * *$ & $0.7823 * *$ & $0.8881 * *$ & $0.897 * *$ & $0.7444 * *$ & $0.5743 * *$ & $0.6095^{* *}$ & $0.6533 * *$ & 0.1232 & -0.0167 & $0.7615^{* *}$ & $0.5754 * *$ & $0.682 * *$ \\
\hline $\mathrm{X} 2$ & & $0.5844 * *$ & $0.529 * *$ & $0.7873 * *$ & $0.7062 * *$ & $0.7489 * *$ & $0.6878 * *$ & 0.2713 & $0.3164 *$ & $0.3415^{*}$ & $0.38^{*}$ & 0.1066 & $0.7335 * *$ & $0.469 * *$ & $0.7649 * *$ \\
\hline $\mathrm{X3}$ & & & $0.6054 * *$ & $0.726^{* *}$ & $0.7715^{* *}$ & $0.8216 * *$ & $0.6876^{* *}$ & $0.4869 * *$ & $0.5296^{* *}$ & $0.598^{* *}$ & 0.2625 & 0.0428 & $0.7983 * *$ & $0.5423 * *$ & $0.785^{* *}$ \\
\hline $\mathrm{X} 4$ & & & & $0.6344 * *$ & $0.5824 * *$ & $0.6526 * *$ & $0.5952 * *$ & 0.2917 & $0.3674 *$ & $0.3629 *$ & $0.3916^{*}$ & -0.1674 & $0.6423 * *$ & $0.4638 * *$ & $0.5151 * *$ \\
\hline X5 & & & & & $0.8087 * *$ & $0.8704 * *$ & $0.8572 * *$ & $0.4099 *$ & $0.4522 * *$ & $0.5034 * *$ & 0.3236 & -0.1127 & $0.8063 * *$ & $0.6505^{* *}$ & $0.7844 * *$ \\
\hline X6 & & & & & & $0.9275^{* *}$ & $0.8096 * *$ & $0.522 * *$ & $0.5401 * *$ & $0.5462 * *$ & 0.211 & 0.1446 & $0.8461 * *$ & $0.4169 *$ & $0.693 * *$ \\
\hline X7 & & & & & & & $0.8678 * *$ & $0.527 * *$ & $0.5686^{* *}$ & $0.6132 * *$ & 0.2607 & 0.0452 & $0.824 * *$ & $0.5721 * *$ & $0.7542 * *$ \\
\hline X8 & & & & & & & & 0.3029 & $0.3404^{*}$ & $0.3477^{*}$ & 0.328 & -0.0209 & $0.7841 * *$ & $0.5509 * *$ & $0.6691 * *$ \\
\hline X9 & & & & & & & & & $0.9768 * *$ & $0.9388 * *$ & 0.0879 & $-0.366^{*}$ & $0.491 * *$ & $0.4646 * *$ & 0.2216 \\
\hline $\mathrm{X} 10$ & & & & & & & & & & $0.9500 * *$ & 0.1021 & $-0.387^{*}$ & $0.5385^{* *}$ & $0.5566^{* *}$ & 0.2902 \\
\hline X11 & & & & & & & & & & & 0.1966 & $-0.396^{*}$ & $0.5382 * *$ & $0.6217 * *$ & $0.376^{*}$ \\
\hline $\mathrm{X} 12$ & & & & & & & & & & & & -0.172 & $0.4087 *$ & 0.2339 & 0.3036 \\
\hline X13 & & & & & & & & & & & & & -0.0604 & $-0.599 * *$ & 0.2095 \\
\hline X14 & & & & & & & & & & & & & & $0.5698 * *$ & $0.7306 * *$ \\
\hline X15 & & & & & & & & & & & & & & & $0.5774 * *$ \\
\hline & \multicolumn{4}{|c|}{$\begin{array}{l}\text { X1- Plant height }(\mathrm{cm}) \\
\text { X5- No. of secondary branches } \\
\text { X9- Days to flower bud initiation } \\
\text { X13- Number of flowers per plant }\end{array}$} & \multicolumn{3}{|c|}{$\begin{array}{l}\text { X2- Plant spread }(\mathrm{cm}) \\
\text { X6- Leaf area }\left(\mathrm{cm}^{2}\right) \\
\text { X10- Days to flowering } \\
\text { X14- Flower diameter }(\mathrm{cr}\end{array}$} & $\begin{array}{l}\text { X3- No. of } \\
\text { X7- Leaf a } \\
\text { X11-Days } \\
\text { X15-Test }\end{array}$ & $\begin{array}{l}\text { leaves } \\
\text { ea index } \\
\text { or } 50 \text { per ce } \\
\text { eight (10 fl }\end{array}$ & $\begin{array}{l}\text { nt flowering } \\
\text { wer weight }\end{array}$ & \multicolumn{4}{|c|}{$\begin{array}{l}\text { X4- No. of primary branches } \\
\text { X8- Dry matter production }(\mathrm{g}) \\
\text { X12- Duration of flowering } \\
\text { X16-Yield per plant }(\mathrm{g})\end{array}$} & \\
\hline
\end{tabular}


Table.2 Genotypic co-efficient of correlation among traits in China aster

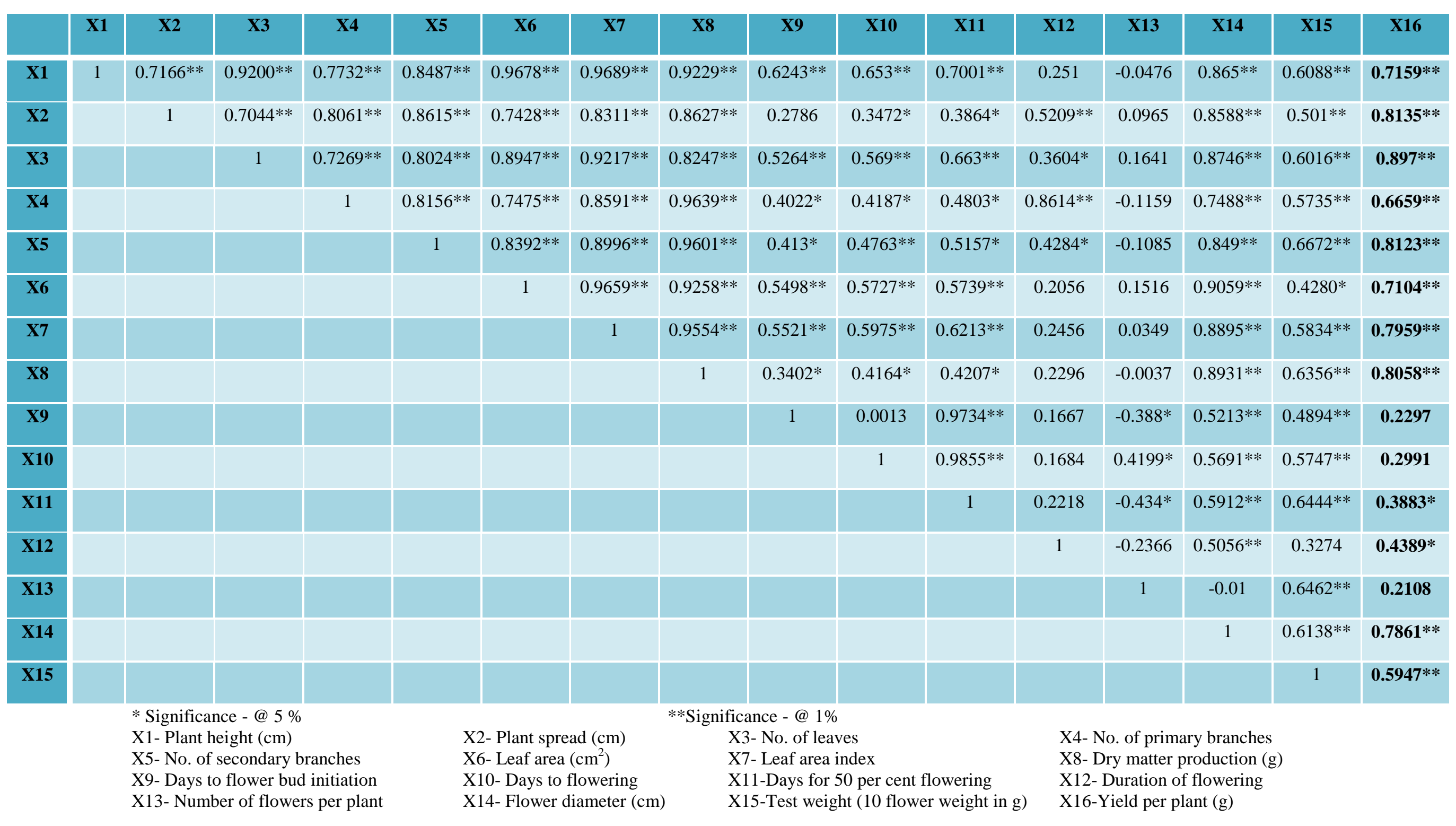


Table.3 Genotypic path coefficients showing direct and indirect effects of different traits on yield per plant in China aster

\begin{tabular}{|c|c|c|c|c|c|c|c|c|c|c|c|c|c|c|c|}
\hline & $\mathrm{X} 1$ & $\mathrm{X} 2$ & X3 & $\mathrm{X} 4$ & X5 & X6 & X7 & X8 & X9 & $\mathrm{X} 10$ & X11 & $\mathrm{X} 12$ & $\mathrm{X} 13$ & X14 & X15 \\
\hline $\mathrm{X} 1$ & 0.2302 & 0.1649 & 0.2117 & 0.178 & 0.1953 & 0.2227 & 0.223 & 0.2124 & 0.1437 & 0.1503 & 0.1611 & 0.0578 & -0.011 & 0.1991 & 0.1401 \\
\hline $\mathrm{X} 2$ & -0.0012 & -0.0016 & -0.0011 & -0.0013 & -0.0014 & -0.0012 & -0.0013 & -0.0014 & -0.0005 & -0.0006 & -0.0006 & -0.0008 & -0.0002 & -0.0014 & -0.0008 \\
\hline X3 & 0.2988 & 0.2288 & 0.3248 & 0.2361 & 0.2606 & 0.2906 & 0.2993 & 0.2678 & 0.171 & 0.1848 & 0.2153 & 0.1171 & 0.0533 & 0.2841 & 0.1954 \\
\hline $\mathrm{X} 4$ & -0.0333 & -0.0347 & -0.0313 & -0.0431 & -0.0351 & -0.0322 & -0.037 & -0.0415 & -0.0173 & -0.018 & -0.0207 & -0.0371 & 0.005 & -0.0322 & -0.0247 \\
\hline X5 & 0.5006 & 0.5081 & 0.4732 & 0.4811 & 0.5898 & 0.495 & 0.5306 & 0.5663 & 0.2436 & 0.2809 & 0.3042 & 0.2526 & -0.064 & 0.5007 & 0.3935 \\
\hline X6 & 0.1256 & 0.0964 & 0.1161 & 0.097 & 0.1089 & 0.1298 & 0.1253 & 0.1201 & 0.0713 & 0.0743 & 0.0745 & 0.0267 & 0.0197 & 0.1176 & 0.0555 \\
\hline $\mathbf{X 7}$ & -0.338 & -0.2899 & -0.3215 & -0.2997 & -0.3138 & -0.337 & -0.3488 & -0.3333 & -0.1926 & -0.2084 & -0.2167 & -0.0857 & -0.0122 & -0.3103 & -0.2035 \\
\hline X8 & -0.3544 & -0.3313 & -0.3167 & -0.3702 & -0.3687 & -0.3555 & -0.3669 & -0.384 & -0.1306 & -0.1599 & -0.1616 & -0.0882 & 0.0014 & -0.343 & -0.2441 \\
\hline X9 & 0.01 & 0.0044 & 0.0084 & 0.0064 & 0.0066 & 0.0088 & 0.0088 & 0.0054 & 0.0159 & 0.016 & 0.0155 & 0.0027 & -0.0062 & 0.0083 & 0.0078 \\
\hline $\mathrm{X} 10$ & -0.2017 & -0.1073 & -0.1758 & -0.1293 & -0.1471 & -0.1769 & -0.1846 & -0.1286 & -0.3093 & -0.3089 & -0.3044 & -0.052 & 0.1297 & -0.1758 & -0.1775 \\
\hline X11 & -0.1192 & -0.0658 & -0.1129 & -0.0818 & -0.0878 & -0.0977 & -0.1058 & -0.0716 & -0.1658 & -0.1678 & -0.1703 & -0.0378 & 0.0739 & -0.1007 & -0.1097 \\
\hline X12 & 0.041 & 0.0851 & 0.0589 & 0.1407 & 0.07 & 0.0336 & 0.0401 & 0.0375 & 0.0272 & 0.0275 & 0.0362 & 0.1634 & -0.0387 & 0.0826 & 0.0535 \\
\hline X13 & -0.0197 & 0.0399 & 0.0678 & -0.0479 & -0.0449 & 0.0627 & 0.0144 & -0.0015 & -0.1604 & -0.1736 & -0.1794 & -0.0978 & 0.4134 & -0.0041 & -0.2671 \\
\hline X14 & -0.1675 & -0.1663 & -0.1693 & -0.1449 & -0.1643 & -0.1754 & -0.1722 & -0.1729 & -0.1009 & -0.1102 & -0.1144 & -0.0979 & 0.0019 & -0.1936 & -0.1188 \\
\hline X15 & 0.3649 & 0.3003 & 0.3607 & 0.3438 & 0.4 & 0.2566 & 0.3498 & 0.381 & 0.2934 & 0.3445 & 0.3863 & 0.1963 & -0.3874 & 0.368 & 0.5995 \\
\hline $\begin{array}{l}\text { Correlation } \\
\text { with yield }\end{array}$ & 0.7159 & 0.8135 & 0.897 & 0.6659 & 0.8123 & 0.7104 & 0.7959 & 0.8058 & 0.2297 & 0.2991 & 0.3883 & 0.4389 & 0.2108 & 0.7861 & 0.5947 \\
\hline
\end{tabular}

Residual effect $=0.158$

$\mathrm{X} 1$ - Plant height $(\mathrm{cm})$

X5- No. of secondary branches

X9- Days to flower bud initiation

X13- Number of flowers per plant

Diagonal (bold) values indicate direct effects;
X2- Plant spread $(\mathrm{cm})$
X6- Leaf area $\left(\mathrm{cm}^{2}\right)$
X10- Days to flowering
X14- Flower diameter $(\mathrm{cm})$
X3- No. of leaves
X7- Leaf area index
X11-Days for 50 per cent flowering
X15-Test weight (10 flower weight in $\mathrm{g}$ )
X4- No. of primary branches
X8- Dry matter production $(\mathrm{g})$
$\mathrm{X} 12$ - Duration of flowering
X16-Yield per plant $(\mathrm{g})$ 
Fig.1 Genotypic path coefficients showing direct and indirect effects of different traits on yield per plant in China aster

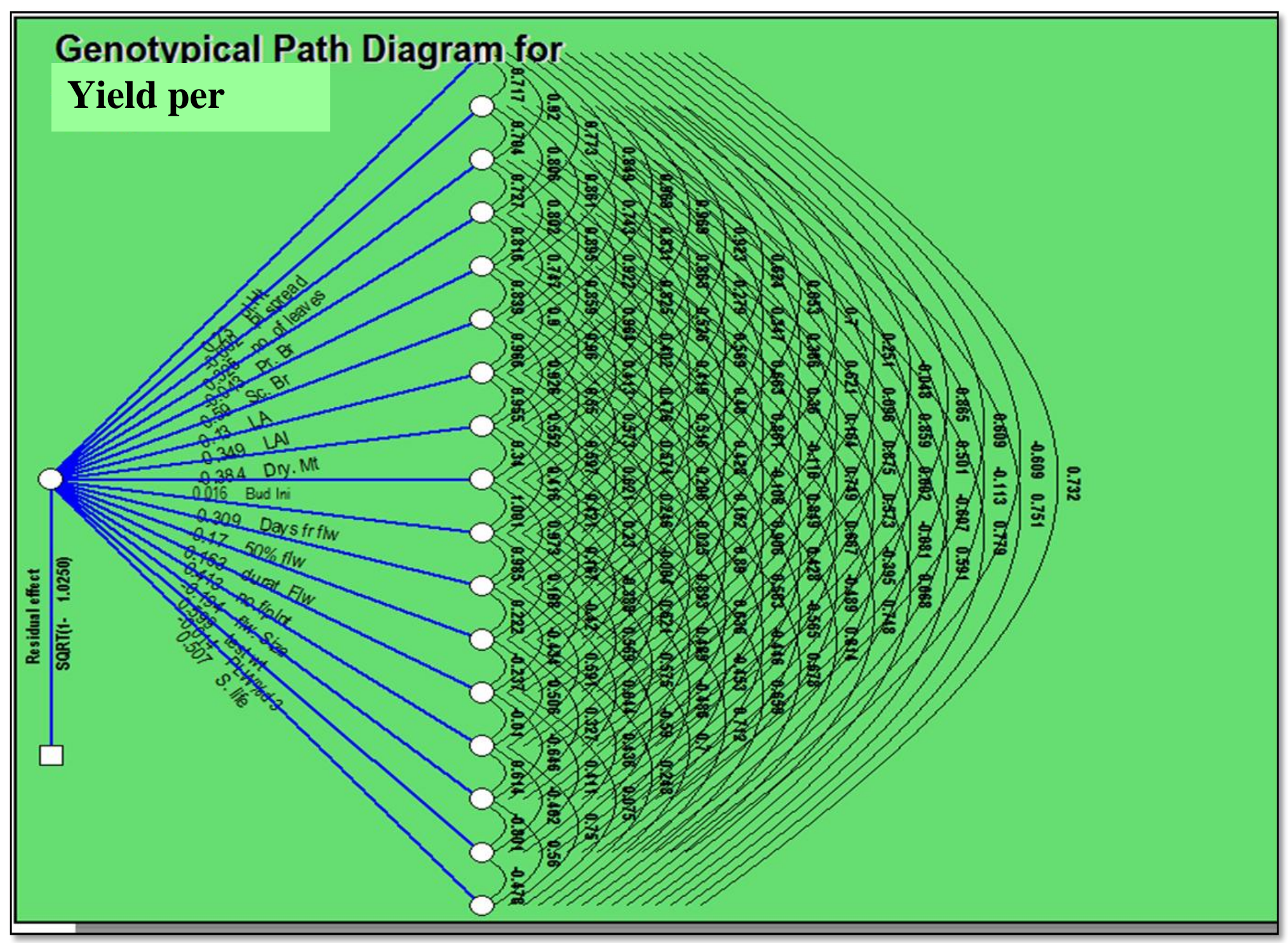


Fig.2 Phenotypic co-efficient of correlation among traits in China aster

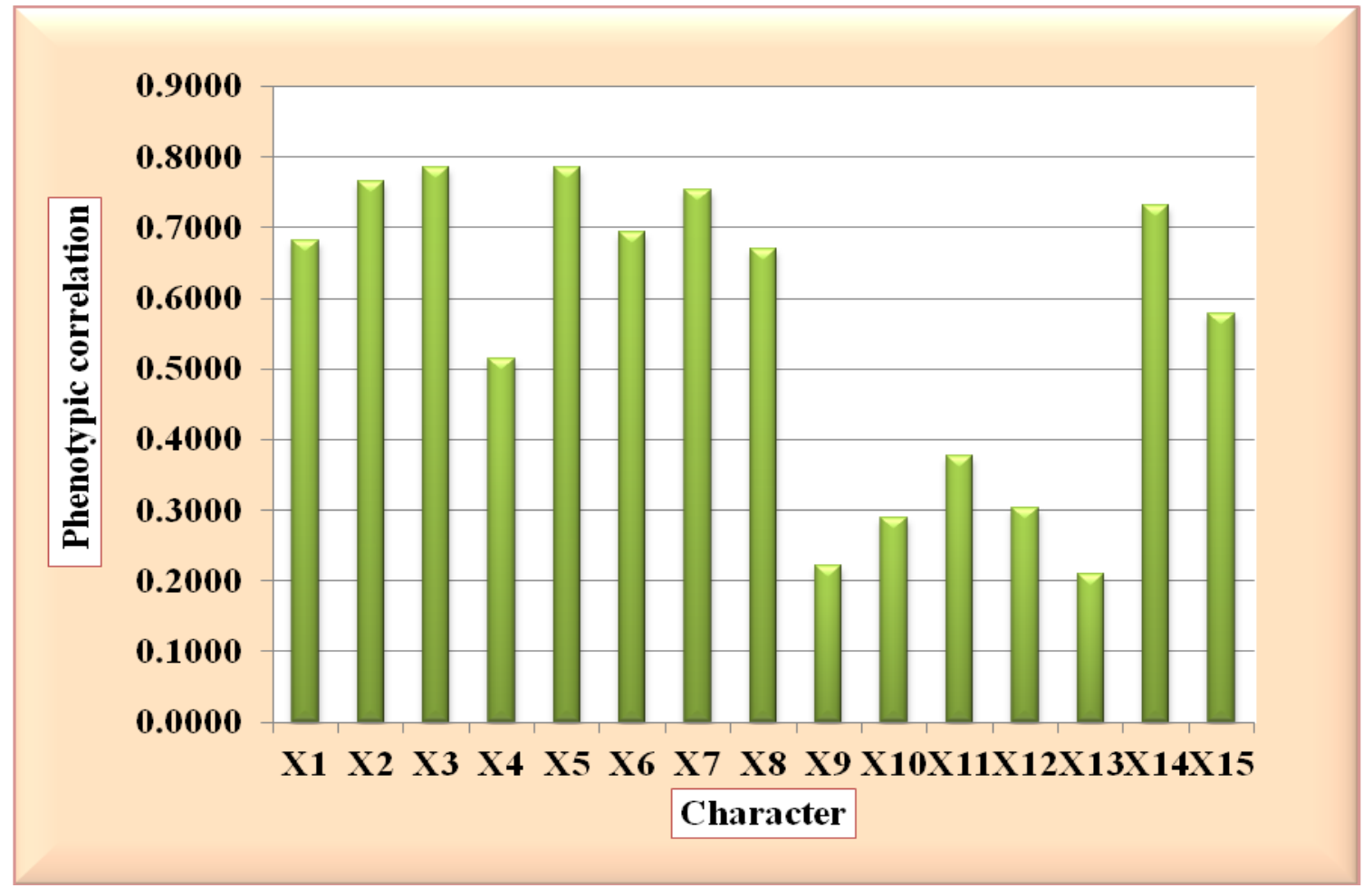

Fig.3 Genotypic co-efficient of correlation among traits in China aster

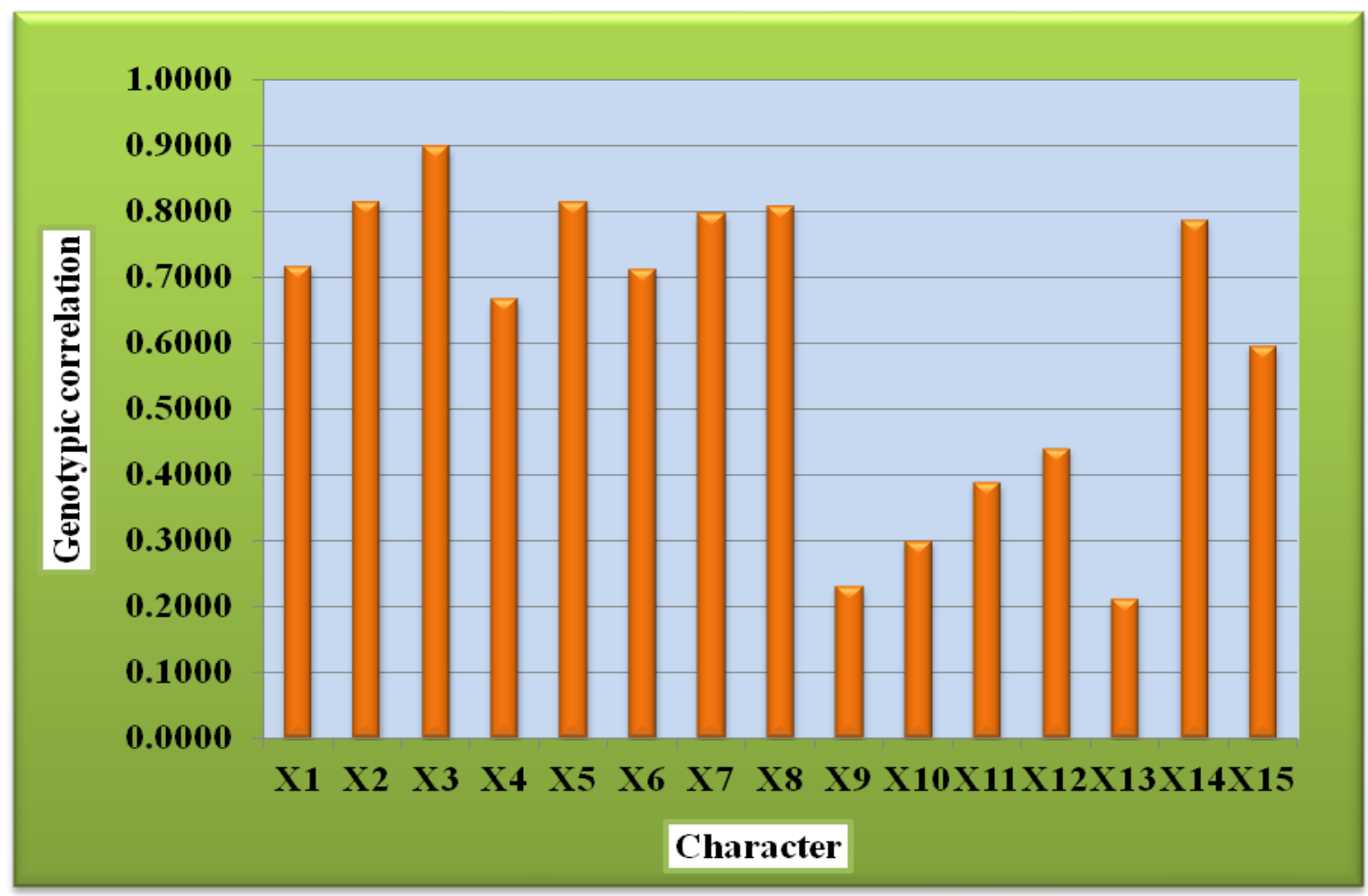


Significantly positive correlation of days to 50 percent flowering (0.3883) with test weight (0.6444) and flower size (0.5912). Flower size (0.7861) recorded significantly positive correlation with test weight (0.6138). The result was in conformity with Baweja (2000), Singh and Sen (2000), Sirohi and Behera (2000), Kumar et al., (2003) and Shantappa et al., (2015).

\section{Path analysis}

Knowledge of degree of association of yield with its components is of great importance, because yield is not an independent character, but it is the resultant of the interactions of a number of component characters among themselves as well as with the environment in which the plant grows. Further each character is likely to be modified by action of genes present in the genotypes of plant and also by the environment and it becomes difficult to evaluate this complex character directly. Therefore, correlation study of yield with its component traits has been executed to find out the yield contributing traits.

Among all the characters studied test weight (0.5995) had highest positive direct effect on flower yield per plant followed by number of secondary branches (0.5898), number of flowers per plant $(0.4134)$, number of leaves (0.3248), plant height $(0.2302)$, duration of flowering (0.1634), leaf area (0.1298) and days to flower bud initiation (0.0159), whereas negative direct effect was executed by dry matter $(-0.384)$ followed by leaf area index (-0.3488), days to flowering (-0.3089), flower size (-0.1936), days to 50 per cent flowering (-0.1703), number of primary branches (-0.0431) and plant spread (-0.0016) at genotypic level. Residual effect was found to be $(0.158)$.

The maximum positive indirect effect of secondary branches (0.5663) via dry matter, test weight (0.3863) via 50 per cent flowering, number of leaves (0.2993) via leaf area index, plant height (0.2230) via leaf area index, duration of flowering (0.1407) via primary branches, days to flowering (0.1297) via number of leaves per plant, leaf area (0.1256) via plant height, 50 per cent flowering (0.0739) via number of flowers per plant, number of flowers per plant (0.678) via number of branches, flower bud initiation (0.0088) via leaf area and leaf area index, primary branches (0.005) via number of flowers per plant, flower size (0.0019) via number of flowers per plant, dry matter (0.0014) via number of flowers per plant were recorded on flower yield per plant at genotypic level. Similar results are reported by Kumar et al., (2012) and Manjula and Nataraj (2016).

From the present investigation it can be concluded that among the twelve genotypes, Phule Ganesh White had recorded maximum flower yield per plant and it was positively and significantly correlated with test weight, plant spread, number of secondary branches and leaf area at genotypic level. Test weight $(0.5995)$ had highest positive direct effect on flower yield per plant followed by number of secondary branches (0.5898). Maximum indirect negative effect of test weight estimate via number of flowers per plant.

\section{Acknowledgement}

To the University of Agricultural Sciences, College of Agriculture Raichur for providing research facilities is gratefully acknowledged.

\section{References}

Baweja, H. S., 2000. Correlation studies in China aster (Callistephus chinensis Nees.). Indian J. Hill Farm, 13 (1/2): 93-94.

Desai, B. L., 1967. Flower description in 
China aster (Callistephus chinensis). In: Seasonal flowers. ICAR Publication, New Delhi, pp. 53-56.

Dewey, J. R. and Lu, K. H., 1959. Correlation and path analysis of components of crested wheat grass seed production. Agron. J., 51: 515-518.

Kumar, M. and Chattopadhyay, T. K., 2002. Evaluation of chrysanthemum cultivars for commercial cultivation. Environ. Eco, 20 (1): 49-51.

Kumar, M., Kumar, S., Singh, M. K., Malik, S. and Kumar, A., 2012. Studies on correlation and path analysis in chrysanthemum (Dendranthema grandiflora Tzvelev.). International $J$. Pl. Res., 25 (2): 62-65.

Manjula, B. S. and Nataraj, S. K., 2016. Genetic correlation and path coefficient analysis in dahlia (Dahlia variabilis L.) genotypes under hill zone of Karnataka. The Bioscan, 11 (2):1089-1092.

Panse, U. G. and Sukhatme, B. V., 1967.
Statistical methods for agricultural workers, ICAR Publication, New Delhi, pp. 100-161.

Shantappa, T., Katagi, Abhishek, Jagadeesha, R. C. and Halesh, G. K., 2015. Studies on genotypic evaluation and correlation studies in China aster [Callistephus chinensis (L.) Nees]. Indian Res. J. Genet. Biotech, 7 (2): 179 - 186.

Singh, D. and Sen, N. L., 2000. Genetic variability, heritability and genetic advance in marigold. J. Orn. Hort., (New series), 36 (2): 75-78.

Sirohi, P. S. and Behera, T. K., 2000. Genetic variability in chrysanthemum. J. Orn. Hort., (New Series), 3 (1): 34-36.

Zosiamliana, J. H., Reddy, G. S. N. and Rymbai, H., 2012. Growth, flowering and yield characters of some cultivars of China aster (Callistephus chinensis Nees.). J. Nat. Prod. Plant Resources, 2 (2): 302-305.

\section{How to cite this article:}

Naikwad, D., K. Kandpal, M.G. Patil, A. Hugar and Kulkarni, V. 2018. Correlation and Path Analysis in China Aster [Callistephus chinensis (L) Nees]. Int.J.Curr.Microbiol.App.Sci. 7(02): 3353-3362. doi: https://doi.org/10.20546/ijcmas.2018.702.401 